\title{
EXPRESSION OF CONNEXINE 43 IN THE SEMINIFEROUS EPITHELIUM OF WHITE MICE DURING TESTICULAR ONTOGENESIS: IMMUNOHISTOCHEMISTRY AND IN SITU HYBRIDIZATION
}

Ahmed E. Zayed ${ }^{1,2}$, Mona A. Ali ${ }^{3}$, Amin Hassanin ${ }^{4}$, Anne Hild , Ralph Brehm ${ }^{5}$, Klaus Steger ${ }^{5}$

${ }^{1}$ Department of Anatomy and Histology, Faculty of Veterinary Medicine, Assiut University, Egypt.

${ }^{2}$ Department of Urology and Pediatric Urology, University of Giessen, Germany.

${ }^{3,4}$ Department of Anatomy and Histology, Faculty of Veterinary Medicine, Kafr El-Shaikh University, Egypt.

${ }^{5}$ Institute of Anatomy, Histology and Embryology, University of Giessen, Germany.

\begin{abstract}
Immunohistochemistry and in situ hybridization were used to elucidate the distribution of connexine 43 (Cx43) protein and its mRNA in mice seminiferous epithelium during testicular ontogenesis. Cx43 protein expresses itself in mice male gonads as early as the premordia germ cells reach the gonadal blastema at 12 days postcoitum $(d p c)$ indicating its importance in testicular development. It was expressed mainly in the basal portions of testicular cords throughout pre- and postnatal periods of gonadal development. Cx43 mRNA was expressed more strongly in germ cells than in supporting cells. Cx43 protein expression was found to be stage dependant being expressed strongly in stage VII (which is characterized by retraction of the main bulk of Sertoli cells to basal locations allowing better visualization of the inter Sertoli cell junction complexes which represent the main site of $\mathrm{Cx} 43$ expression).
\end{abstract}




\section{INTRODUCTION}

Connexins are the protein subunits of gap junction channels through which the direct exchange of ions, metaboloites and second messengers occurs (Sà̀z et al., 1989; Elfgang et al., 1995; Kumar and Gilula, 1996).

The role of $\mathrm{Cx} 43$ in testicular development has also been documented. The number of germ cells in fetal testis of CX43 Knock-out mice is significantly reduced (Juneja et al., 1999). In addition the junctional intercellular communications between Sertoli cells and between Sertoli cell and spermatogonia is considered to play a key role in regulation of both proliferation and differentiation of germ cells (Fischer et al., 2005). From the earliest stage of gonadal development, $\mathrm{Cx} 43$ is expressed in principal cell types that participate in the control of male fertility.

During postnatal development, $\mathrm{Cx} 43$ has been reported to express itself in basal portions of Sertoli cells of newly born mice. It shifts to an adluminal location during the first two weeks, but then it relocalizes itself peripherally (Brovo-Moreno et al., 2001).

Several evidences have been presented for the requirement of $\mathrm{Cx} 43$ in the control of fertility. For example, it has been shown that decreased Cx43 expression in adult Sertoli cells is associated with disturbances in spermatogenesis in both human (Steger et al., 1999) and mouse (Batias et al., 1999).

At mRNA level, the cellular localization of $\mathrm{Cx} 43$ has been determined by in situ hybridization only during postnatal development (Batias et al., 2000). Investigations at this level during prenatal development was not conducted so far. The present study aims to visualize the expression of CX43 in different cellular components of the seminiferous epithelium during pre- and postnatal development using immunohistochemical and in situ hybridization. 


\section{MATERIALS AND METHODS}

\section{Animals and tissue:}

This study was conducted on 54 white mice embryos aging 12 to 20 dpc, 6 embryos for each of the above 9 prenatal ages. Each embryo was cut transversely just caudal to the thoracic limbs into two halves. The caudal half was fixed in Bouin's fixative for 24 hours then processed for paraffin embedding. Cosecutive $5 \mu \mathrm{m}$ thick sections were cut from each block, mounted on superfrost slides (Menzel-Glaser, Germany) and dried for 24 hours at $37^{\circ} \mathrm{C}$. In addition three mice aging 5, 10 days and an adult one were used for the postnatal study. The testis were collected from these animals, fixed in Bouin' fixative and processed for paraffin sectioning as above.

\section{Cx43-IHC:}

Immunohistochemical staining for $\mathrm{Cx} 43$ were performed on consecutive paraffin sections. Briefly, sections were microwave treated for $30 \mathrm{~min}$ at 1000 watts in sodium citrate buffer $(\mathrm{pH} \mathrm{6.0)}$ ), blocked with $5 \%$ BSA for $30 \mathrm{~min}$ and incubated with the polyclonal anti-cx43 primary antibody (1:250; Zytomed, Berlin, Germany) over night at $4{ }^{\circ} \mathrm{C}$. Sections were then exposed to the secondary antibody (1:50; mouse antirabbit IgG; DAKO) followed by the third antibody (1:50; rabbit-antimouse IgG; DAKO) and finally mouse alkaline phosphatase anti-alkaline phosphatase (APAAP) antibody complex (1:100, DAKO) for $30 \mathrm{~min}$ each. The immunoreaction was visualized using HistoMark Red (KPL). For each immunoreaction, control incubations were performed by substituting buffer for the primary antibody. Cx43 IHC was repeated at least twice.

Production of Digoxigenin (DIG)-labeled cRNA probes for ISH DIGlabeled cRNA-probes were generated as described previously by Brehm et al. (2006). The DNA sequence of the human Cx43 gene (Accession 
AF 151980) was generated using a touch-down PCR with primers Cx43F and $\mathrm{Cx} 43 \mathrm{R}$ (MWG, Ebersberg, Germany ${ }^{\mathrm{y}}$ ). PCR conditions were as follows: $1 \mathrm{x} 95{ }^{\circ} \mathrm{C}$ for $3 \mathrm{~min}, 15 \mathrm{x}$ [ $95{ }^{\circ} \mathrm{C}$ for $1 \mathrm{~min}, 66^{\circ} \mathrm{C}$ for $1 \mathrm{~min}, 72$ ${ }^{\circ} \mathrm{C}$ for $2 \mathrm{~min}$ ], $45 \mathrm{x}$ [ $95^{\circ} \mathrm{C}$ for $1 \mathrm{~min}, 62^{\circ} \mathrm{C}$ for $1 \mathrm{~min}, 72{ }^{\circ} \mathrm{C}$ for $2 \mathrm{~min}$ ], $72{ }^{\circ} \mathrm{C}$ for $10 \mathrm{~min}$. The $138 \mathrm{bp}$ PCR-product of the human $\mathrm{Cx} 43$-gene was subcloned in pGEM-T vector (Promega, Mannheim, Germany). Plasmids were transformed in the XL1-Blue E. coli strain (Stratagene, Heidelberg, Germany) and extracted by column purification, according to the manufacturers instruction (Qiagen, Hilden, Germany). After sequencing, vectors containing the $\mathrm{Cx} 43$-insert were digested with NcoI and NotI (New England Biolabs, Frankfurt, Germany) for the production of sensecRNA (NcoI) and antiSense-cRNA (NotI), respectively. Subsequently, in-vitro transcription was performed using the 10x RNA-DIG LabelingMix (Boehringer Mannheim, Mannheim, Germany) and RNApolymerases T7 and SP6 (Promega).

\section{$Y=C \times 43$ 5'- cca tet cta act cec atg cac agc $-3^{\prime}$ (F) \\ 5' - tgg cac gac tge tgg ctc tgc tt - 3' (R) 138 bp}

\section{Cx43-ISH:}

ISH was performed on consecutive sections as described previously. ${ }^{x}$ Briefly, deparaffinized tissue sections were incubated in active DEPC water for $2 \times 12 \mathrm{~min}$ at $40{ }^{\circ} \mathrm{C}$, postfixed in $4 \%$ paraformaldehyde for $10 \mathrm{~min}$, exposed to $20 \%$ acetic acid and prehybridized in $20 \%$ glycerol for $30 \mathrm{~min}$. Sections were then incubated with the DIG-labeled sense or antisense cRNA probes. Both cRNAs were used at a dilution of 1:25 in hybridization-buffer containing $50 \%$ deionized formamide, $10 \%$ dextran sulfate, $2 \mathrm{x}$ standard saline citrate (SSC), 1x Denhardt's solution, $10 \mu \mathrm{g} / \mathrm{ml}$ salmon sperm DNA (SigmaAldrich, Taufkirchen, Germany) and $10 \mu \mathrm{g} / \mathrm{ml}$ yeast t-RNA (Sigma). Hybridization was performed overnight at $40{ }^{\circ} \mathrm{C}$ in a humidified chamber containing $50 \%$ formamide in 2x SSC after posthybridization washes. Subsequently, sections were incubated with the anti-DIG Fab-

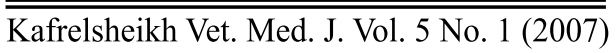


antibody conjugated to alkaline phosphatase (Boehringer) overnight at 4 ${ }^{\circ} \mathrm{C}$. Staining was visualized by developing sections with NBT/BCIP (nitroblue-tetrazolium/5-bromo-4-chloro-3-indolyl-phosphate; KPL, Gaithersburg, MD, USA) in a humidified chamber protected from light. Finally, sections were rehydrated for $5 \mathrm{~min}$ in deionized water and then dehydrated through successive baths of ethanol and xylol, and mounted in Eukitt resin (Merck, Darmstadt, Germany). For each test, negative controls were performed using DIG-labeled cRNA sense probes. ISH was repeated at least twice.

\section{RESULTS}

\section{Immunohistochemistry:}

Cx43 was expressed in mice testis as early as $12 \mathrm{dpc}$. It appeared in the form of deeply stained small dots surrounded by irregular shadow. The reaction included the areas of contact between some supporting cells as well as in contact areas between some supporting and germ cells (Fig. 1).

By the appearance of testicular cords, Cx43 was localized mostly in basal locations of these cords. The reaction was limited to junctional contacts between supporting cells and between supporting and germ cells. The adluminal expression was demonstrated to sporadic locations (Fig. 2).

By advancement of fetal ages, Cx43 expression became more intensified in basal portions of testicular cords (Fig. 3). In full-term fetuses, the cellular components in testicular cords seemed to be relatively decreased, possibly due to increased gonadal size and this became reflected on $\mathrm{Cx} 43$ reaction which showed a slight down regulation (Fig. 4). 
During the early postnatal period, Cx43 expression was up regulated in testicular cords and included almost all inter-Sertoli cell junctions (Fig. 5). On reaching maturity, Cx43 displayed variable reactions in tubular compartment of the testis. The seminiferous tubules in stages prior to spermiation (stages VII and VIII), showed the strongest reactivity. However tubules with younger deeply inserted spermatids (in stage XII) showed little or even no Cx43 expression (Fig. 6).

\section{In situ hybridization:}

Cx43 mRNA was detected in testicular cords as early as $14 \mathrm{dpc}$. Its expression in germ cells cytoplasm was more evident than in Sertoli cells throughout pre- and postnatal development. The whole germ cell cytoplasm stained positively with $\mathrm{Cx} 43$ mRNA. It was demonstrated in the beginning in both basal and adluminal (Figs. $7 \& 8$ ), then after, it shifted to basal portions in late prenatal (Figs. 9) and prepuberal periods (Figs. 10 \& 11). In mature testis, Cx43 mRNA was investigated in spermatogonia, primary spermatocytes and basal portions of Sertoli cells particularly in stage VII of spermatogenic cycle (Fig. 12).

\section{LEGENDS}

Figs. 1-6: Localization of $\mathrm{Cx} 43$ protein in mice testis during pre- and postnatal development. Cx43 can be detected as early as $12 \mathrm{dpc}$ in the form of dark dots surrounded by irregular shadow between some blastemal cells (thick arrow) as seen in fig.1. After appearance of testicular cords at $14 \mathrm{dpc}$ (Fig. 2), the punctuate expression of Cx43 (arrow) is demonstrated mainly in basal tubular locations. The inset in fig. 2 demonstrates 
expression of $\mathrm{Cx} 43$ between supporting (S) and Germ cells (G). By advancement of fetal ages and at $17 \mathrm{dpc}$ (Fig. 3), the Cx43 expression becomes up regulated and includes almost all inter Sertoli cell junctions. In full term fetuses at 20dpc (Fig. 4), the Cx43 expression seems to be down regulated. During the early postnatal period, $\mathrm{Cx} 43$ expression was up regulated in testicular cords and included almost all inter-Sertoli cell junctions at 10 dpc (Fig. 5). On reaching maturity (fig. 6), Cx43 showed the strongest expression in stage VII of spermatogenesis (arrow) and is nearly not expressed in stage XII.

Fig. 7-12: Expression of $\mathrm{Cx} 43$ mRNA in mice testis during pre- and postnatal development. It starts at $14 \mathrm{dpc}$ (Fig. 7) in the form of light brown to brown cytoplasmic staining. It is demonstrated mainly in germ cell cytoplasm which is restricted firstly in adluminal locations at $14 \mathrm{dpc}$ and $15 \mathrm{dpc}$ (Fig. 8). It then starts to occupy basal locations at $20 \mathrm{dpc}$ (Fig. 9), 5 days postpartum (Fig. 10) and 10 days postpartum (Fig. 11). In mature testis (Fig. 12), Cx43 mRNA was investigated in spermatogonia, primary spermatocytes and basal portions of Sertoli cells particularly in stage VII of spermatogenic cycle. 


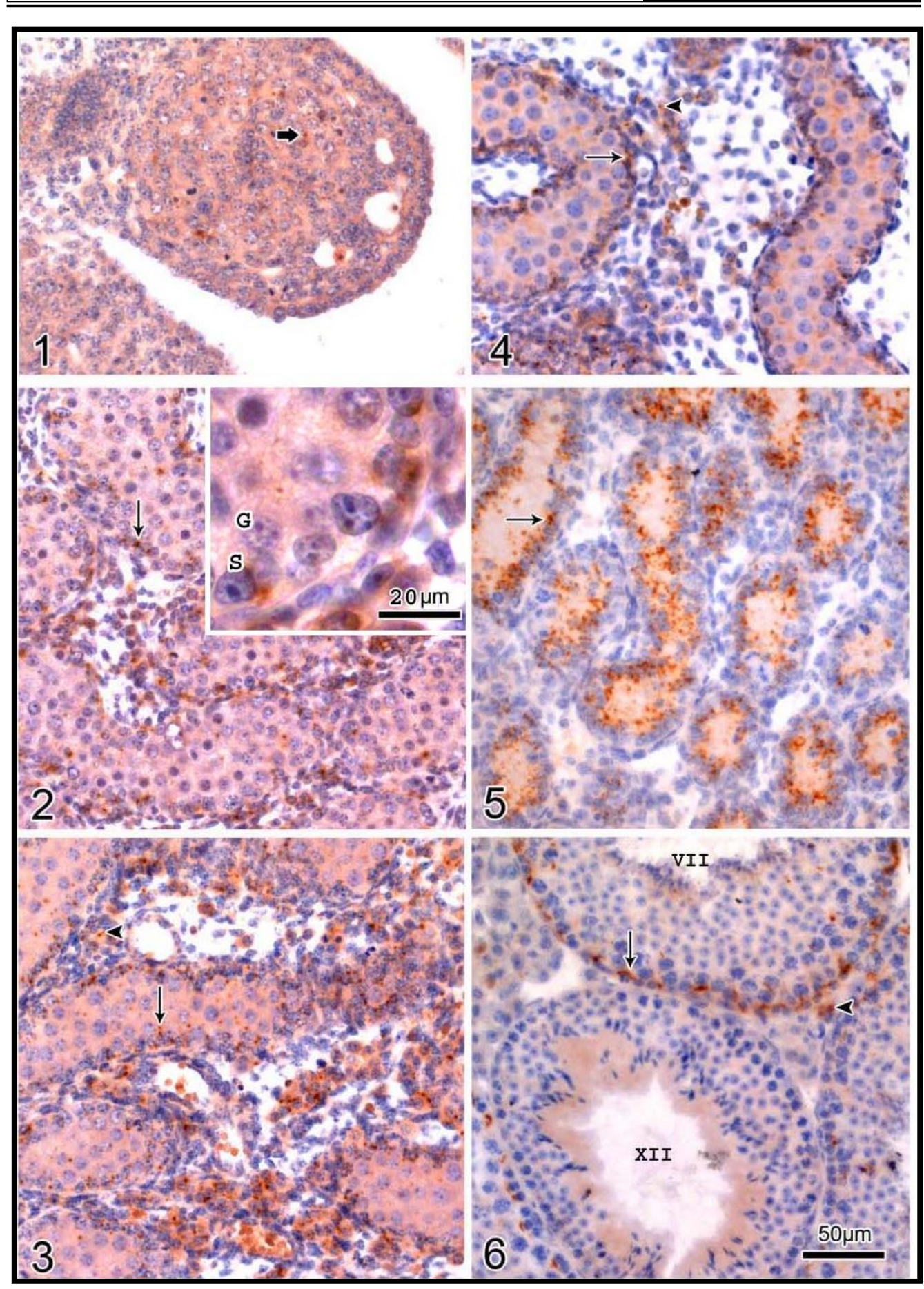

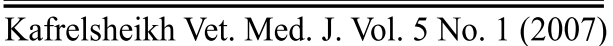




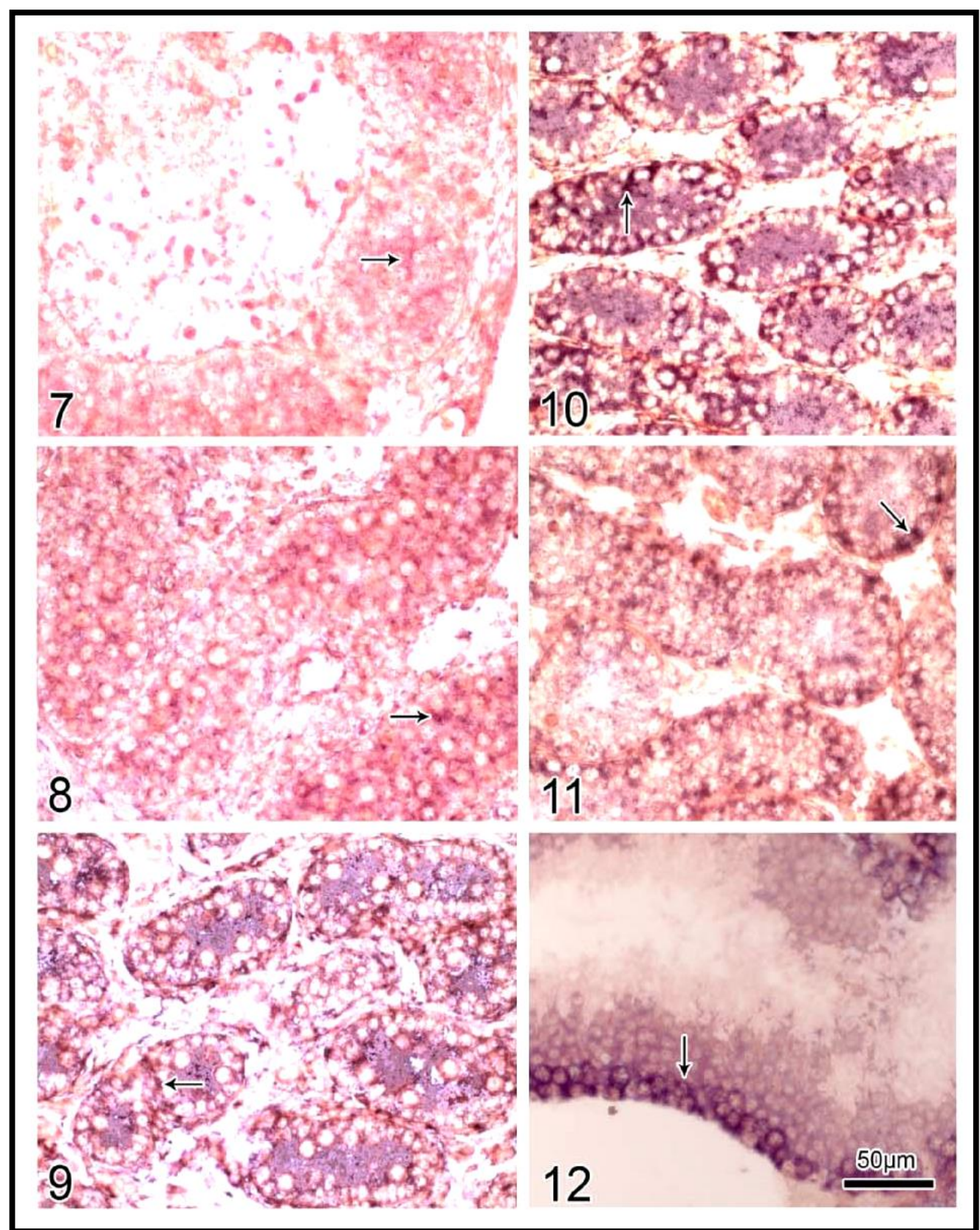

$\overline{\text { Kafrelsheikh Vet. Med. J. Vol. } 5 \text { No. } 1 \text { (2007) }}$ 


\section{DISCUSSION}

The present study showed for the first time a full coverage of the expression of $\mathrm{Cx} 43$ protein and its mRNA in mice testis during the preand postnatal periods of development. In agreement with PerezArmendariz et al. (2001) Cx43 protein is detectable in mice male gonad as early as the primordial germ cells reach the gonadal blastema (11.5-12 $\mathrm{dpc})$. In the current study, $\mathrm{Cx} 43$ protein was demonstrated in the form of sporadic deeply stained dots in contact areas between some blastemal cells which were not yet organized to form testicular cords. This very early expression points to an important role of $\mathrm{Cx} 43$ in testicular development. This is supported by the statement of Brovo-Moreno et al. (2001) that $\mathrm{Cx} 43$ plays other roles in gonadal development besides control of spermatogenesis. This raises the possibility that $\mathrm{Cx} 43$ may be included in the control of germ cells proliferation and survival. In this concern, Juneja et al. (1999) have reported that $\mathrm{Cx} 43$ deficient mice experience a significant decrease in germinal cells throughout embryonic life.

The present work emphasized that $\mathrm{Cx} 43$ protein was located mainly in the basal compartment of testicular cords throughout both pre- and postnatal development, the adluminal expression was sporadic in some cords. Cx43 protein was investigated mainly in gap junctional complexes between adjacent supporting cells as well as between supporting and germ cells. The basal location of the former cells explains the basal expression of $\mathrm{Cx} 43$ throughout testicular ontogenesis. Unlikely, Batias et al. (2000) have mentioned that $\mathrm{Cx} 43$ protein is first detected in the adluminal compartment of the growing seminiferous tubules before it becomes progressively located in the basal compartment at latter ages. This inconsistence in their results could be attributed to pictures obtained from tangential sections in testicular cords which may give false adluminal expression of $\mathrm{Cx} 43$. 
In situ hybridization revealed that $\mathrm{Cx} 43$ mRNA was expressed more strongly in germ cells than in the supporting cells. The presence of Cx43 ISH signals in germ cells is consistent with previous observations of Batias et al. (2000) and supports the presence of gap junctions between supporting and germ cells reported by Enders (1993). Our findings enable us to postulate that $\mathrm{Cx} 43 \mathrm{mRNA}$ is primarily synthesized in germ cells before being transferred to the neighbouring supporting cells. This is supported by the description of homotypic, heterotypic or heteromeric channels containing Cx43 (Bukauskas et al., 1995; Elfgang et al., 1995; Elenes et al., 1999; Oh et al., 1999) and in situ dye transfer (Batias et al., 2000) between supporting and germ cells.

The present investigation supports previous reports that $\mathrm{Cx} 43$ protein and its mRNA were dependant on the stage of spermatogenesis. Our results agree partially with those of Risley et al. (1992); Tan et al. (1996); Lablack et al. (1998) and Batias et al. (2000) that $\mathrm{Cx} 43$ protein and mRNA were expressed strongly in stage VII, i.e. prior to spermiation. However, our work emphasized that after spermiation, Cx43 was down regulated to be nearly absent in stage XII. It is not clear why Cx43 expression increases in stage VII of spermatoigenesis. The late spermatids appear to be a major regulator of Sertoli cell function in adult mammalian testis (Jegou, 1993). A concomitant reduction in the expression of $\mathrm{Cx} 43$ and the number of elongated spermatids has been reported in Ebourrife mutant house mice (Lalouette et al., 1996). This has raised the possibility of the implication of elongated spermatids, existing in stage VII, in modulation of Cx43 synthesis (Batias et al, 1999). In our opinion, stage VII of spermatogenbesis is also characterized by retraction of the main bulk of Sertoli cells masses to basal locations that may allow better visualization of the inter Sertoli cell junctions which represent the main site of $\mathrm{Cx} 43$ expression. 


\section{REFERENCES}

- Batias, C.; Defamine, N.; Lablack, A.; Thepot, D.; Fenichel, P.; Segretain, D. and Pointis, G. (1999): Modified expression of testicular gap junction connexin43 during normal spermatogenetic cycle and in altered spermatogenesis. Cell Tissue Res. 298: 113-121.

- Batias, C.; Siffroi, J.P.; Fenichel, P.; Pointis, G. and Segretain, D. (2000): Connexin43 gene expression and regulation in the rodent seminiferous epithelium. J. Histochem. Cytochem., 48: 793-805.

- Bravo-Moreno, J.F.; Diaz-Sanchen, V.; Montoya-Flores, J.G.; Lamoyi, E.; Safez, J.C. and Perez-Armendariz EM (2001): expression of connexin43 in mouse Leydig, Sertoli and germinal cells at different stages of postnatal development. Anat. Rec., 264: 13-24.

- Brehm, R.; Ruettinger, C.; Fischer, P.; Gashaw, I.; Winterhager, E.; Kliesch, S.; Bohle, R.M.; Steger, K. and Bergmann, M. (2006): Transition from pre-invasive carcinoma in situ to seminoma is accompanied with a reduction of connexin43 expression in Sertoli cells and germ cells. Neoplasia, 8: 499-509.

- Bukauskas,F.F.;Elfgang, C.; Willecke, K. and Weingart, R. (1995): Heterotypic gap junction channels (connexin26-connexin32)violate the paradigm of unitary conductance. Pfluegers Arch., 429: 870-872.

- Elenes, S.; Rubart, M. and Moreno, A.P. (1999): Junctional communication between isolated pairs of canine atrial cells is mediated by homogenous and heterogenous gap junction channels. J. Cardiovasc. Electrophysiol., 10: 990-1004. 
- Elfgang, C.; Ekert, R.; Lichtenberg-Frate, H.;Butterweck, A.;Traub, O.; Klein, R.A.; Hulser, D.F. and Willecke, K. (1995): Specific permeability and selective formation of gap junction channels in connexion transfected HeLa cells. J. Cell Biol., 129: 805-817.

- Enders, G.C. (1993): Sertoli-Sertoli and Sertoli-Germ cell communications. The Sertoli cell in Russel LD Griswold MD, eds. Clearwater, FL, Cache River Press, 447-4460.

- Fischer,P.;Brehm,R.;Konrad,L.; Hartmann, S.; Kliesch, S.; Bohle, R.M. and Bergmann, M. (2005): Connexin33: A rodent-specific member of the gap junction protein family? J. Androl., 26: 75-84.

- Jegou, B. (1993): The Sertoli-germ cell communication network in mammals. Int. Rev. Cytol., 147: 25-96.

- Juneja, S.C.; Barr, K.J.; Enders, G.C. and Kidder, G.M. (1999): Effects in the germ line and gonads of mice lacking connexin43. Biol. Reprod., 60: 1263-1270.

- Kumar, N.M. and Gilula, N.B. (1996): The gap junction communication channels. Cell, 84: 381-388.

- Lablack, A.; Bourdon, V.; Defamie, M.; Batias, C.; Mesnil, M.; Fenischel,P.;Bointis, G. and Segretain, D. (1998): Ultrastructure and biochemical evidence for gap junction and connexin43 expression in a clonal Sertoli cell line: A potential model in the study of junctional complex formation. Cell Tissue Res., 294: 279-287. 
- Lalouette, A.A.; Lablack, A.; Guenet, J.L.; Montagutelli, X. and Segretain, D. (1996): Male sterility caused by sperm cell-specific structural abnormalities in Ebourrifé, a new mutation of the house mice. Biol. Reprod., 55: 355-363.

- Oh, S.; Rubin, J.B.; Bennett, M.V.L.; Verselis, V.K. and Bargiello, T.A. (1999): Molecular determinates of electrical rectification of signal channel conductants in gap junctions formed by connexin26 and 32. J. Gen. Physiol., 114: 339-364.

- Perez-Armendariz,E.M.;Lamoyi, E.; Mason, J.L.; Cisneros-Armas, D.; Luu-Tche, V. and Bravo-Moreno, J.F. (2001): Developmental regulation of connexin43 expression in fetal mouse testicular cells. Anat. Rec., 264: 237-246.

- Risley, M.S.; Tan, I.P.; Roy, C. and Saez, J.C. (1992): Cell, age-and stage- dependant distribution of connexin43 gap junctions in testis. J. Sci., 103: 81-96.

- Sae z, J.C.; Connor, J.A.; Spray, D.C. and Bennett, M.V.L. (1989): Heterotypic gap junctions are permeable to the second messenger, Inositol 1, 4, 5-triphosphate, and to calcium ions. Proc. Natl. Acad. Sci. USA, 86: 2708-2712.

- Steger, K.; Tens, F. and Bergmann, M. (1999): Expression of connexin43 in human testis. Histochem. Cell Biol., 112: 215-220.

- Tan, I.P.; Roy, C. ; Saez, J.C. ; Saez, C.G. ; Paul, D.L. and Risley, M.S. (1996): Regulated assembly of connexin 33 and connexin 43 into rat Sertoli cell gap junctions. Biol. Reprod., 54: 1300-1310. 
ظهور الكونكسين 43 فى النسيج الطلائى المنوى للفأر الأبيض أثناء مر احل تطور

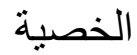

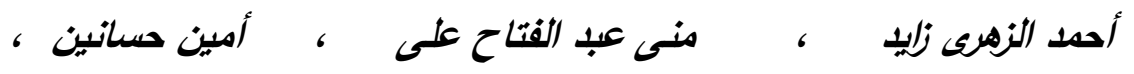

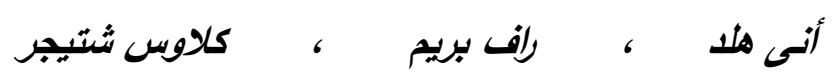

أستخدم فى هذه الدراسة كل من الكيمياء النسيجية المناعية والتهجين المحلى لإستنضاح نوزيع بروتين وال ر ن ا الناقل للكونكسين 43 فى النسيج الطلائى للانيبيات المنوية لخصية الفأر الأبيض أثناء مراحل تطورها المختلفة حيث ظهر بروتين الكونكسين فى خصية أجنة الفأر عند عمر أثثى عشر يوما للحمل مما يدل على أهيته فى تطور الخصية. ولقد تمركز بشكل خاص فى الجزء القاعدى من الأحبال الخصوية طوال مراحل ما قبل وبعد الولادة من التطور ـ أما ال ر ن ا الناقل فقد عبر عن نفسه بشكل أكثر قوة فى الخلايا الجرثومية أكثر منها فى الخلايا الدعامية. كذلك فإن وجود بروتين الكونكسين فى الأنيبيات المنوية للفئران البالغة تركز بشكل أقوى فى المرحلة السابعة للدورة المنوية والتىى تتميز

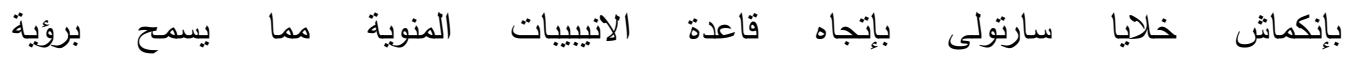
أوضح لمناطق الإتصال لهذه الخلايا مع بعضها البعض والتى تمثل المناطق الرئيسية لظهور

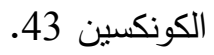

